\title{
PENGARUH DERAJAT STRES SEBAGAI MEDIATOR PADA HUBUNGAN ANTARA COPING DAN KESEHATAN MENTAL
}

\author{
Sherly Rosita Edi Sentani' ${ }^{1}$, Achmad Djunaidi², R. Urip Purwono ${ }^{3}$ \\ ${ }^{1,2,3}$ Fakultas Psikologi Universitas Padjadjaran \\ Jl. Raya Bandung Sumedang KM.21 Kabupaten Sumedang, Jawa Barat 45363 \\ E-mail: sherlyrositaes@gmail.com
}

\begin{abstract}
ABSTRAK
Penelitian ini bertujuan untuk melihat peran derajat stres sebagai mediator pada hubungan coping terhadap kesehatan mental. Partisipan penelitian ini yaitu 469 orang mahasiswa di Kota Bandung (laki-laki=138, perempuan=331; rentang usia $17-24$ tahun). Data diperoleh melalui tiga alat ukur, yaitu Perceived Stress Scale, Cope Inventory, dan Kesehatan Mental. Analisis statistik PROCESS digunakan untuk menguji analisis peran mediasi. Hasil penelitian menunjukkan derajat stres berperan sebagai mediasi antara hubungan bentuk emotion focused coping, problem focused coping, dan maladaptive coping terhadap kesehatan mental. Artinya, proses reappraisal dapat menjelaskan efektivitas penggunaan bentuk coping tertentu yang dapat memengaruhi kesehatan mental. Proses reappraisal ditunjukkan dalam bentuk derajat stres, dimana terjadi penurunan maupun peningkatan derajat stres. Mahasiswa yang termasuk dalam kategori sehat mental ketika pemilihan bentuk coping yang digunakan dapat menurunkan tingkat stres. Adapun bentuk coping yang dinilai dapat menurunkan tingkat stres, yaitu emotion focused coping dan problem focused coping. Sementara itu, maladaptive coping termasuk ke dalam kategori tidak sehat mental, hal ini disebabkan terjadinya peningkatan derajat stres seseorang hingga memunculkan symptom-simptom gangguan kesehatan mental.
\end{abstract}

Kata kunci: coping; derajat stres; kesehatan mental; mahasiswa; reappraisal

\begin{abstract}
This research aims to determine the role of the degree of stress as a mediator in the relationship between coping and mental health. The participants of this research are 469 students in Bandung (male $=138$, female $=331$; age range 17-24 years). The instruments in this study are Perceived Stress Scale, Cope Inventory, and Mental Health. Data analysis techniques used in this study is PROCESS to test the mediation role analysis. The results showed the degree of stress plays a role as a mediation between the relationship between emotion focused coping, problem focused coping and maladaptive coping on mental health. This means that the reappraisal process can explain the effectiveness of using certain forms of coping that can affect mental health. The reappraisal process is shown in terms of the degree of stress, where there is a decrease or an increase in stressful levels. Students who are in the mental health category when choosing the form of coping used can reduce stress levels. The forms of coping that are considered to reduce stress levels are emotion focused coping and problem focused coping. Meanwhile, maladaptive coping is categorized as mentally unhealthy, this is due to an increase in a person's stressful level can lead to symptoms of mental disorders.
\end{abstract}

Keywords: coping; college students; degree of stress; mental health; reappraisal 


\section{PENDAHULUAN}

Kesehatan mental masih menjadi salah satu momok permasalahan kesehatan yang signifikan di dunia. Menurut data World Health Organization (WHO) pada tahun 2016 berdasarkan jumlah global dunia, terdapat sekitar 35 juta orang mengalami depresi, 60 juta orang mengalami bipolar, 21 juta orang mengalami skizofrenia, serta 47,5 juta orang mengalami demensia. Sedangkan di Indonesia, berdasarkan data Riset Kesehatan Dasar (Riskedas) pada tahun 2013 menunjukkan prevalensi gangguan mental emosial ditunjukkan dengan simptomsimptom depresi dan kecemasan pada usia 15 tahun ke atas mencapai 14 juta orang atau $6 \%$ dari jumlah penduduk Indonesia. Sedangkan prevalensi gangguan jiwa berat, seperti skizofrenia mencapai sekitar 400.000 orang atau sebanyak 1,7 per 1000 penduduk. Hal ini menunjukkan prevalensi gangguan jiwa berat nasional sebesar 1,7 per mil, yang artinya 1-2 orang dari 1000 penduduk Indonesia mengalami gangguan jiwa (Badan Penelitian dan Pengembangan Kesehatan Kementrian Kesehatan RI, 2013). Tingginya angka gangguan jiwa di Indonesia meningkat setiap tahunnya. Menurut data Riskesdas tahun 2018, prevalensi gangguan mental emosional meningkat dari $6 \%$ menjadi $9,8 \%$ dari jumlah penduduk di Indonesia.

Permasalahan mengenai kesehatan mental tidak terlepas dari fenomena bunuh diri. Di Indonesia, angka bunuh diri terus meningkat hingga $1,6-1,8$ tiap 100.000 penduduk. Adapun kejadian bunuh diri tertinggi berada pada kelompok usia remaja dan dewasa muda ( $15-24$ tahun). Data WHO tahun 2012 menunjukkan bahwa fenomena bunuh diri di Indonesia berada pada kelompok masyarakat yang rentan terhadap sumber tekanan psikososial, yaitu pengungsi, remaja, dan masyarakat sosial ekonomi rendah. Sedangkan data di Pusat Data dan Informasi Kementerian Kesehatan RI mencatat bahwa terdapat 812 kasus bunuh diri di seluruh wilayah Indonesia pada tahun 2016. Jika ditelurusi menggunakan pencarian secara online dan offline, kasus bunuh diri di Indonesia didominasi oleh mahasiswa.

Perilaku atau pemikiran bunuh diri merupakan salah satu simptom seseorang mengalami gangguan kesehatan mental. Penjelasan terkait gangguan kesehatan mental terdapat di International Classification of Diseases (ICD) atau Diagnostic and Statistical Manual of Mental Disorder (DSM), sedangkan di Indonesia yaitu Pedoman Penggolongan dan Diagnosis Gangguan Jiwa. Salah satu gangguan kesehatan mental yang memiliki simptom terkait dengan perilaku bunuh diri yaitu gangguan mood. Hal ini menjelaskan pentingnya untuk mengetahui kondisi kesehatan mental seseorang.
Salah satu konsep teori yang menjelaskan mengenai munculnya gangguan kesehatan mental dikenal dengan istilah diathesis-stress model, yaitu suatu predisposisi atau kerentanan seseorang mengalami gangguan tertentu sebagai hasil interaksi dengan kondisi stres pada indivdu. Selain itu, seseorang dikatakan mengalami suatu gangguan atau abnormalitas dijelaskan dengan four D's, dimana salah satunya yaitu distress. Penjelasan terkait dengan istilah ini menunjukkan bahwa salah seorang mengalami gangguan kesehatan mental dikarenakan seseorang mengalami stres (Nolen-Hoeksema, 2010). Hal ini sejalan dengan pengertian sehat mental yang dikemukakan oleh World Health Organization (2014), yaitu " a state of well being in which every individual realizes his or her own potential, can cope with the normal stresses of life, can work productively and fruitfully, and is able to make a contribution to her or his community". Berdasarkan definisi tersebut, terdapat beberapa hal yang dapat dikategorikan sebagai sehat mental, yaitu ketika seseorang dapat menggunakan kemampuannya, menanggulangi permasalahan atau stressor, mampu untuk bekerja secara produktif dan berkontrubusi di komunitasnya. Berdasarkan definisi ini, seseorang dapat sehat mental ketika mampu menanggulangi atau mengatasi permasalahan atau stressor-nya.

Salah satu konsep teori yang mencoba untuk menjelaskan terkait dengan konsep stres adalah Lazarus \& Folkman (1984), yang mana teori stres dijelaskan berdasarkan transactional model. Model ini mencoba menjelaskan berdasarkan level analisis (social, psychological, dan physiological) yang dapat dijelaskan prosesnya berdasarkan causal antecedents, mediating processes, dan adaptational outcomes (immediate effects dan longterm effects). Hal ini menjelaskan bahwa kondisi terdahulu (causal antecendents) memengaruhi proses mediasi (mediating processes), kemudian memengaruhi outcomesnya. Penjelasan terkait outcomes pada konsep teori ini yaitu kondisi well being atau berada pada kondisi sehat mental.

Berdasarkan transactional model, dijelaskan bahwa stres disebabkan adanya proses bagaimana individu mempersepsi atau menilai situasi stressor sebagai stressful. Lazarus \& Folkman (1984) menjelaskan bahwa stres adalah hubungan antara individu dengan lingkungan yang dinilai oleh individu sebagai tuntutan atau membebani sumber daya dan membahayakan kesejahteraannya yang dapat memunculkan respon fisiologis dan psikologis.

Penjelasan terkait dengan stres yang ada pada mahasiswa dapat dilihat dari hasil survei yang dilakukan oleh The American College Health Association pada tahun 2017. Dari hasil survei tersebut, ditemukan bahwa $45.1 \%$ dari mahasiswa mengalami stres tinggi dan $12 \%$ melaporkan sangat mengalami stres. Adapun beberapa sumber stres pada mahasiswa meliputi akademik (47,5\%), keuangan 
$(31,8 \%)$, relasi interpersonal $(30,9 \%)$, dan masalah tidur (30\%). Sedangkan berdasarkan survei yang dilakukan oleh Buckinghamshire Health Authority pada tahun 2002, ditemukan bahwa terdapat berbagai macam kelompok stressor bagi mahasiswa, yaitu academic stressor, placement stressor, organizational stressor, dan personal stressor (Behere, dkk, 2001). Academic stressor adalah stressor yang berkaitan dengan akademik, seperti tugas kuliah, deadline, dan peringkat akademik. Placement stressor merupakan stressor yang berkaitan dengan lingkungan, seperti hubungan dengan orang lain, terlalu banyak tanggung jawab, dan lingkungan fisik yang buruk. Organizational stressor merupakan stressor yang berkaitan dengan aktivitas organisasi mahasiswa. Personal stressor merupakan stressor yang berkaitan dengan masalah personal, seperti masalah keuangan dan kurangnya dukungan sosial.

Stressor dinilai oleh individu sebagai stressful. Oleh karena itu, untuk mengetahui bagaimana kondisi individu, dapat dilihat berdasarkan derajat stres atau tingkat stres pada mahasiswa. Stres merupakan salah satu faktor resiko memiliki gangguan kesehatan mental. Proses coping dibutuhkan sebagai mediator individu untuk mengetahui pengaruh stres dengan kesehatan mental. Terdapat beberapa penelitian yang membahas mengenai pengaruh stres dengan kesehatan mental. Pada penelitian yang dilakukan oleh Chen \& Lu (2009) mengemukakan bahwa banyak aspek terkait dengan pendidikan yang memiliki hubungan dengan depresi dan isu-isu terkait dengan perilaku (seperti perilaku bunuh diri). Hal ini juga sejalan dengan penelitian yang dilakukan oleh Agarwal (2011) yang mengemukakan bahwa stres akademik pada mahasiswa memiliki korelasi negatif dengan performa akademik dan kesehatan mental. Selain itu juga ditemukan bahwa performa akademik memiliki korelasi positif pada kesehatan mental.

Hubungan antara stres pada individu dengan kesehatan mental dapat dijelaskan berdasarkan penelitian yang dilakukan oleh Cohen dkk (1983), yang menjelaskan bahwa stres memiliki hubungan yang kuat dengan kesehatan mental dan fisik yang buruk. Hubungan ini berkaitan dengan pengukuran derajat stres pada individu yang memiliki hubungan kuat dengan simptom-simptom depresi. Adapun depresi ini sebagai salah satu bentuk gangguan kesehatan mental. Penelitian yang dilakukan oleh Chen \& Lu (2009) mengemukakan bahwa stres di dunia pendidikan memiliki hubungan dengan depresi dan isu-isu terkait dengan perilaku (seperti perilaku bunuh diri).

Dampak akan kesehatan mental pada mahasiswa ini dapat berkaitan dengan performa akademik yang akan dicapai. Penelitian yang dilakukan oleh Agarwal (2011) mengemukakan bahwa stres pada mahasiswa memiliki korelasi negatif dengan performa akademik dan kesehatan mental. Selain itu juga ditemukan bahwa performa akademik memiliki korelasi positif pada kesehatan mental. Hal ini menunjukkan bahwa pada mahasiswa yang mengalami stres akan memengaruhi kesehatan mental dan berdampak pada performa akademik di perkuliahan. Kajian akan stres sebenarnya tidak selalu berdampak buruk pada individu. Stres diperlukan untuk proses adaptasi yang lebih baik di lingkungan. Ketika seseorang dihadapkan pada situasi stressful dan berdampak negatif pada dirinya, maka perlu ada strategi tertentu untuk menanggulanginya. Oleh karena itu, perlu dilakukan suatu upaya untuk bisa menanggulangi dan mengatasi stres yang dirasakan oleh mahasiswa.

Upaya yang dilakukan mahasiswa untuk menanggulangi atau mengatasi stres menurut Lazarus \& Folkman (1984) disebut sebagai Coping. Penjelasan terkait dengan stres, coping, dan kesehatan mental dijelaskan oleh Lazarus \& Folkman dalam kerangka teorinya yaitu transactional model, dimana proses coping merupakan mediasi antara stres dengan kesehatan mental sebagai outcomes. Ketika seseorang dihadapkan pada situasi atau kondisi yang stressful, maka ada upaya secara terus menerus untuk menanggulangi atau mengatasinya. Diperlukan suatu upaya yang efektif untuk dapat mengatasi ataupun menanggulangi stres pada mahasiswa. Untuk melihat apakah efektif atau tidaknya seseorang mengatasi stres, maka dilakukan penilaian kembali berdasarkan efek jangka pendek yang dirasakan. Adapun efek jangka pendek yang dirasakan ini yaitu perubahan emosi yang dirasakan. Pada seseorang yang mengalami stres, maka terdapat perubahan emosi yang dapat dirasakan, yaitu seperti takut, cemas, panik, kesal, marah, dan emosi negatif lainnya. Jika seseorang melakukan coping, maka akan ada perubahan emosi menjadi lebih tenang atau emosi positif lainnya. Selain itu, stres tidak hanya dihadapkan pada satu situasi saja tetapi, berbagai macam situasi dan konteks yang dihadapkan. Adapun efek jangka panjang yang dapat dirasakan oleh seseorang yaitu terkait dengan kesehatan mental, kesehatan fisik, dan seberapa optimal seseorang dalam relasi sosialnya serta keberfungsiannya di dalam lingkungannya.

Mediasi proses coping merupakan poin penting untuk dapat mengetahui kesehatan mental seseorang ketika dihadapkan pada situasi stress. Lazarus \& Folkman (1984) menjelaskan bahwa bentuk coping dibagi menjadi dua, yaitu problem focused coping dan emotion focused coping. Sementara itu, Carver dkk (1989) membagi bentuk coping menjadi adaptif dan maladaptif. Coping yang adaptif adalah penanggulangan yang dapat mengatasi stres, baik secara langsung ke permasalahannya, maupun menanggulangi emosi, sedangkan coping yang maladaptif adalah upaya yang tidak efektif untuk mengatasi permasalahan atau emosi. Meskipun upaya 
tersebut dilakukan, tetapi sifatnya sementara dan jika dihadapkan kembali pada stressor, maka akan dinilai sebagai situasi yang stressful.

Problem focused coping adalah perilaku yang bertujuan untuk memecahkan masalah atau melakukan sesuatu untuk mengubah sumber stres. Terdapat upaya individu untuk merubah lingkungan atau stressor. Problem focused coping mengarah pada penyelesaian masalah seperti informasi mengenai suatu masalah, mengumpulkan solusisolusi yang dapat dijadikan alternatif, mempertimbangkan alternatif dari segi biaya dan manfaatnya, memilih alternatif, dan menjalani alternatif yang dipilih (Lazarus \& Folkman, 2006). Individu juga secara langsung menghadapi, mengontrol, dan mengatur tugas-tugas yang stressful.

Carver dkk (1989) menurunkan problem focused coping menjadi lima bentuk. Yang pertama ialah active coping, yaitu suatu proses pengambilan langkah untuk mencoba menyiasati sumber stres atau mengurangi efeknya. Kedua adalah planning, yaitu memikirkan bagaimana langkah-langkah atau strategi untuk menangani stressor. Yang ketiga ialah seeking social support for instrumental reasons, yaitu memanfaatkan sumber daya berupa dukungan sosial yang dimiliki untuk mengatasi stres berupa saran, nasihat, bantuan, atau memberikan informasi. Keempat adalah suppersion of competing activities, yaitu mengesampingkan kegiatan lain dan menghindari hal-hal yang dapat mengganggu proses penanganan stressor. Yang kelima adalah restraint coping, yaitu menunggu saat yang tepat untuk melakukan suatu upaya sehingga dapat mengatasi stressor secara efektif.

Emotion focused coping adalah perilaku yang bertujuan untuk mengatasi stres dengan cara mengatur respon emosional dalam rangka menyesuaikan diri dengan dampak yang akan ditimbulkan oleh suatu kondisi atau situasi yang dianggap penuh tekanan. Menurut Lazarus \& Folkman (2006), emotion focused coping merupakan sekumpulan proses kognitif yang diarahkan untuk mengurangi tekanan emosional dan mencakup strategi menghindari, meminimalisasi, menjaga jarak, selektif memilih perhatian, perbandingan positif, dan mencari nilai positif dari sebuah peristiwa negatif.

Carver dkk (1989) menurunkan emotion focused coping menjadi enam bentuk. Yang pertama adalah seeking social support for emotional reasons, yaitu mencari dukungan moral, simpati, atau pengertian dari orang lain. Yang kedua adalah positive reinterpretation and growth, yaitu menilai kembali suatu situasi yang menimbulkan stres secara positif. Yang ketiga ada denial, yaitu menolak untuk percaya bahwa stressor itu ada. Keempat adalah acceptance, yaitu menerima situasi penyebab stres atau menyesuaikan diri dengan keadaan yang dialami. Yang kelima adalah humor, yaitu mencoba untuk membuat sebuah candaan mengenai stressor. Yang keenam adalah turning to religion, yaitu mengembalikan permasalahan yang dihadapi pada agama, rajin beribadah, dan memohon pertolongan Tuhan.

Carver dkk (1989) menjelaskan bahwa maladaptive coping sebagai kecenderungan coping yang kurang bermanfaat dan kurang efektif dalam mengatasi sumber stres. Adapun upaya yang dilakukan dapat berfokus pada masalah atau emosi. Carver dkk (1989) menurunkan maladaptive coping menjadi lima bentuk. Yang pertama adalah focusing on venting of emotions, yaitu kecenderungan untuk melepaskan emosi yang dirasakan. Kedua adalah behavioral disengangement, yaitu mengurangi usaha yang dilakukan untuk mengadapi situasi yang menimbulkan stres, menyerah, bahkan tidak melakukan apapun terhadap sumber stres. Yang ketiga adalah mental disengangement, yaitu melakukan aktivitas alternatif untuk mengalihkan atau melupakan stressor. Keempat adalah alcohol drug disengangement, yaitu berusaha melepaskan diri dari masalah dengan menggunakan alkohol atau obatobatan. Yang kelima adalah self blame, yaitu individu menyalahkan diri sendiri atas terjadinya permasalahan yang dihadapi.

Berdasarkan penelitian yang dilakukan oleh Struthers dkk (2000) menjelaskan bahwa bentuk coping memiliki peran penting bagaimana mahasiswa menanggulangi kejadian stressful. Kemampuan mahasiswa dalam menanggulangi stres dapat membantu untuk menurukan derajat stres, sedangkan ketidakmampuan seseorang dalam mengatasi stres, dalam hal ini yaitu menggunakan bentuk coping maladaptif, dapat berdampak negatif baik secara fisik maupun psikologis. Dalam hal ini, penggunaan bentuk coping maladaptif seperti menyalahkan diri sendiri, denial, dan menyerah, dapat menjadi prediksi dari depresi, kecemasan, dan tingginya derajat stres.

Penelitian yang sudah dilakukan lebih berfokus kepada satu topik tertentu, sehingga peneliti belum menemukan literatur atau penelitian yang membahas pengaruh penggunaan coping dengan kesehatan mental yang berdasarkan kerangka transactional model yang diperantarai oleh derajat stres.

\section{METODE}

Partisipan penelitian ini adalah 469 mahasiswa di Kota Bandung (laki-laki = 138; perempuan $=331)$. Rentang usia partisipan yaitu 1724 tahun $(\mathrm{M}=19,84 ; \mathrm{SD}=1,731)$. Adapun karakteristik partisipan penelitian, yaitu mahasiswa aktif S1 yang berkuliah di universitas yang terdapat di Kota Bandung. Partisipan berkuliah di Perguruan Tinggi Negeri (PTN) dan Perguruan Tinggi Swasta (PTS). Sampel diperoleh dengan teknik non probability sampling dalam bentuk convenience 
sampling, yaitu sampel diperoleh secara sukarela saat mereka bersedia menjadi partisipan penelitian.

Penelitian ini memiliki tiga variabel, yaitu derajat stres, coping, dan kesehatan mental. Data penelitian diperoleh dengan mengisi kuesioner secara online menggunakan google form. Kuesioner disebarkan secara online menggunakan aplikasi media sosial.

Kuesioner derajat stres menggunakan alat ukur Perceived Stress Scale (Cohen, 1983) yang diadaptasi ke dalam bahasa Indonesia. Kuesioner derajat stres berisikan 13 item berupa pertanyaan dengan lima pilihan jawaban, yaitu tidak pernah, hampir tidak pernah, kadang-kadang, sering, dan sangat sering. Nilai reliabilitas alat ukur ini adalah 0,89 dengan rentang analisis item sebesar 0,37 0,69 .

Kuesioner coping menggunakan alat ukur COPE Inventory (Carver dkk, 1989) yang diadaptasi ke dalam bahasa Indonesia oleh Sentani (2016) dan dikembangkan kembali oleh Sentani (2020). COPE Inventory terdiri dari tiga dimensi bentuk coping, yaitu problem focused coping, emotion focused coping, dan maladaptive coping. Kuesioner ini terdiri dari 64 item berupa pernyataan dengan empat pilihan jawaban, yaitu tidak pernah, jarang, sering, dan selalu. Koefisien reliabilitas alat ukur ini berada dalam rentang $0,81-0,87$.

Kuesioner kesehatan mental menggunakan alat ukur Self Reporting Questionnaire (Beusenberg, Orley, \& WHO, 1994) yang telah dikembangkan oleh Sentani dan Ariani (Sentani, 2020). Kuesioner ini terdiri dari 81 item yang berisikan pernyataan dengan lima pilihan jawaban, yaitu tidak pernah, jarang, kadang-kadang, sering, dan selalu. Cut-off score pada alat ukur ini yaitu $\geq 180$ indikasi memiliki gangguan kesehatan mental dan $<180$ menunjukkan sehat mental. Koefisien reliabilitas alat ukur ini yaitu 0,98 .

Pengumpulan data dilakukan menggunakan kuesioner online yang diisi oleh mahasiswa. Data yang diperoleh dianalisa menggunakan program SPSS (Statistical Package for Social Sciences) versi 22.0 dengan penambahan PROCESS dari Hayes (2013) untuk melakukan uji variabel mediasi.

\section{HASIL DAN PEMBAHASAN}

Setelah dilakukan pengambilan data kepada 469 mahasiswa di Kota Bandung, dilakukan uji analisis regresi mediasi pada uji pengaruh antara bentuk coping terhadap kesehatan mental melalui mediasi derajat stres. Uji model ini dilakukan sesuai dengan transactional model yang dikembangkan oleh Lazarus \& Folkman (1984), yang mana terdapat proses kognitif berupa penilaian terhadap stressor dan coping yang digunakan. Pada model yang umum, diketahui bahwa proses pertama dilakukan penilaian terhadap situasi atau kondisi yang dianggap sebagai situasi stressful. Penilaian akan situasi ini untuk mengetahui derajat stres seseorang. Kemudian dilakukan penilaian lanjutan mengenai bentuk coping yang dipilih untuk mengatasi stressor. Dalam penelitian ini, peneliti mencoba mengukur pengaruh penggunaan bentuk coping terhadap kondisi kesehatan mental melalui mediasi variabel derajat stres sebagai upaya pemahaman mengenai proses reappraisal. Lazarus \& Folkman (1984) mencoba menjelaskan proses penilaian ulang terhadap coping yang dipilih efektif menurunkan derajat stres. Hal ini dikarenakan proses coping bergerak secara dinamis, dimana individu akan secara terus menerus melakukan upaya yang beragam hingga dirasa efektif dalam mengatasi permasalahan.

Penjabaran mengenai coping dibagi menjadi dua kelompok besar, yaitu bentuk coping yang tidak efektif dan bentuk coping yang efektif mengatasi permasalahan. Pengertian ini mengacu pada Carver dkk (1989) yang mencoba melakukan kajian terhadap alat ukur Ways of Coping yang disusun oleh Lazarus \& Folkman (1984). Carver membagi coping menjadi tiga, yaitu problem focused coping, emotion focused coping, dan maladaptive coping. Adapun konsep yang ingin ditunjukkan oleh Carver dkk (1989) adalah penggunaan coping dibagi menjadi dua, yaitu adaptif dan tidak adaptif dalam mengatasi permasalahan. Dalam penelitian ini, coping adaptif dijelaskan melalui problem focused coping dan emotion focused coping. Sementara itu, istilah maladaptive coping menjelaskan bahwa bentuk coping tersebut tidak efektif dalam mengatasi permasalahan. Digunakannya istilah maladaptive coping dalam penelitian ini dikarenakan hipotesis yang ingin diketahui apakah pembagian bentuk coping ini memengaruhi kondisi kesehatan mental.

Penjelasan mengenai kondisi kesehatan mental pada penelitian ini dibagi menjadi dua kategori, yaitu sehat mental dan indikasi gangguan kesehatan mental. Indikasi gangguan kesehatan mental ditunjukkan dengan simptom-simptom yang dirasakan oleh seseorang. Simptom-simptom ini diturunkan berdasarkan acuan ICD, dimana terdapat empat gangguan kesehatan mental yang sering dirasakan oleh mahasiswa, yaitu gangguan mood, gangguan kecemasan, gangguan fisik (somatoform), dan gangguan psikotik. Namun, penelitian ini tidak membagi kondisi mental seseorang berdasarkan keempat gangguan kesehatan mental tersebut. Adapun simptom-simptom yang dirasakan oleh mahasiswa merupakan reaksi yang muncul akibat penilaian seseorang terhadap stressor. Kondisi yang memunculkan seseorang mengalami simptomsimptom berada pada kondisi stressful.

Penjelasan terkait penilaian terhadap stressor dibagi menjadi tiga bagian, yaitu irrelevant, benign positive, dan stressful. Irrelevant yaitu saat mahasiswa menilai bahwa stressor tidak berdampak terhadap kesejahteraannya. Benign positive yaitu saat 
mahasiswa menilai bahwa stressor meningkatkan kesejahteraannya dan memiliki emosi yang positif. Artinya, kondisi yang sedang dihadapi bermakna positif dan menguntungkan baginya. Sedangkan stressful, yaitu saat mahasiswa menilai stressor mengancam kesejahteraannya. Stressor dihayati sebagai situasi yang mengancam, merugikan, dan menantang. Reaksi emosi yang dimunculkan biasanya reaksi yang negatif seperti marah, kesal, atau sedih. Berbeda dengan situasi yang dinilai menantang, dimana mahasiswa akan memunculkan reaksi emosi yang positif seperti bersemangat atau bergairah.

Penelitian ini lebih menekankan kepada penilaian stressor yang dinilai sebagai ancaman atau merugikan sehingga bermakna stressful. Pengertian derajat stres menjelaskan bahwa seberapa tinggi seseorang menilai stressor sebagai kondisi stressful. Artinya, semakin seseorang menilai stressor sebagai sesuatu yang sangat mengancam menunjukkan semakin tinggi seseorang berada dalam kondisi stressful. Tingkat stres dalam penelitian ini sebagai proses penilaian kembali setelah seseorang melakukan bentuk coping tertentu. Setelah mahasiswa melakukan bentuk coping tertentu, maka akan menilai apakah bentuk coping yang dilakukan tersebut efektif atau tidak dalam mengatasi kesehatan mental $(\beta=-0.103 ; p>0,05)$. Artinya, derajat stres berperan sebagai mediasi terhadap pengaruh emotion focused coping terhadap kesehatan mental (-1.827; 95\% CI -2,282, -1,392).

Bentuk maladaptive coping secara signifikan memengaruhi kondisi kesehatan mental ( $\beta$ $\left.=5.413 ; R^{2}=0.464 ; p<0,05\right)$. Bentuk maladaptive coping secara signifikan memengaruhi derajat stres $\left(\beta=-0.445 ; R^{2}=0.593 ; p<0,05\right)$. Derajat stres secara signifikan memengaruhi kesehatan mental $(\beta$ $\left.=0,124 ; R^{2}=0,593 ; p<0,05\right)$. Setelah melalui proses mediasi, bentuk maladaptive coping secara signifikan memengaruhi kesehatan mental $\left(\beta=5,468 ; R^{2}=\right.$ $0.593 p<0,05)$. Artinya, derajat stres berperan sebagai mediasi sebagian terhadap pengaruh maladaptive coping terhadap kesehatan $(2.157 ; 95 \%$ CI 1.756, 2,589).

Pada bentuk problem focused coping dan emotion focused coping memiliki penjelasan yang sama. Dimana bentuk kedua coping ini adalah upayaupaya yang efektif dalam mengatasi permasalahan, baik berfokus terhadap masalah maupun emosi. Hubungan mediasi yang terjadi menjelaskan bahwa semakin sering seseorang menggunakan bentuk coping yang adaptif berfokus terhadap masalah ataupun emosi, maka semakin rendah tingkatan stres dalam menilai stressor. Hal ini membuat individu

Tabel 1. Hasil Analisis Uji Regresi Mediasi Sederhana

\begin{tabular}{lcccccccc}
\hline & \multicolumn{3}{c}{ Jalur a } & \multicolumn{2}{c}{ Jalur b } & \multicolumn{2}{c}{ Jalur c } & \multicolumn{2}{c}{ Jalur d } \\
\cline { 2 - 9 } & $\beta$ & $p$ & $\beta$ & $p$ & $\beta$ & $p$ & $\beta$ & $P$ \\
\hline Problem focused coping & $-0,432$ & $<0,05$ & 5,468 & $<0,05$ & 0,124 & $>0,05$ & $-2,240$ & $<0,05$ \\
Emotion focused coping & $-0,335$ & $<0,05$ & 5,454 & $<0,05$ & 0,103 & $>0,05$ & $-1,725$ & $<0,05$ \\
Maladaptive coping & $-0,445$ & $<0,05$ & 0,124 & $<0,05$ & 5,468 & $<0,05$ & 5,413 & $<0,05$ \\
\hline
\end{tabular}

permasalahan. Ketika penggunaan coping tertentu dinilai efektif, maka dapat menurunkan tingkat stres seseorang. Sebaliknya, ketika penggunaan coping tertentu dinilai tidak efektif, maka tingkat stres seseorang akan berada dalam kondisi sama atau semakin meningkat. Hal ini yang ingin dijelaskan dalam penelitian ini dimana penggunaan bentuk coping tertentu dalam memengaruhi kondisi kesehatan mental mahasiswa melalui penjelasan derajat stres.

Pada Tabel 1 dapat dilihat mengenai hasil analisis uji mediasi ditemukan bahwa derajat stres berperan sebagai mediasi terhadap pengaruh bentuk emotion focused coping, problem focused coping, dan maladapive coping terhadap kesehatan mental

Bentuk emotion focused coping secara signifikan memengaruhi kondisi kesehatan mental $(\beta$ $\left.=-1,725 ; R^{2}=0.063 ; p<0,05\right)$. Bentuk emotion focused coping secara signifikan memengaruhi derajat stres $\left(\beta=-0.335 ; R^{2}=0.135 ; p<0,05\right)$. Derajat stres secara signifikan memengaruhi kesehatan mental $\left(\beta=-0.335 ; R^{2}=0.516 ; p<0,05\right)$. Setelah melalui proses mediasi, bentuk emotion focused coping secara signifikan tidak memengaruhi akan memiliki skor yang rendah terhadap gangguan kesehatan mental dan akan menunjukkan kondisi sehat mental.

Penjelasan ini mengandung makna pentingnya melakukan penilaian kembali setelah menggunakan bentuk coping tertentu dapat memengaruhi kondisi kesehatan mental seseorang. Penggunaan bentuk coping tertentu dapat memengaruhi penilaian seseorang terhadap stressor. Ketika seseorang menggunakan bentuk coping yang

dapat menurunkan derajat stres, maka individu menilai bahwa dirinya telah mengatasi stressor secara efektif, sehingga saat dihadapkan kembali dengan stressor yang sama, maka penilaian terhadap stressor menjadi tidak sama seperti sebelumnya dan dinilai sebagai situasi yang irrelevant atau benign positive.

Dari hasil penelitian ini, didapatkan bahwa bentuk emotion focused coping dan problem focused coping dinilai dapat menurunkan tingkat stressful seseorang, sehingga saat dilakukan secara berulang akan mengarah kepada kondisi sehat mental. Hal ini menunjukkan bahwa penggunaan bentuk emotion focused coping dan problem focused coping dinilai 
efektif mengatasi stressor dan menunjukkan kondisi sehat mental. Hal ini membuat simptom-simptom yang dirasakan terkait dengan kondisi gangguan kesehatan mentalpun akan berkurang.

Penjelasan mengenai gangguan kesehatan mental ditunjukkan dengan simptom-simptom yang dirasakan oleh individu disebabkan penghayatan terhadap stressor sebagai reaksi stres yang dirasakan. Adapun reaksi stres ini dapat berupa reaksi emosi, perubahan perilaku, kognisi, relasi sosial, dan motivasi yang berdampak kepada keberfungsian individu dalam kehidupan sehari-hari. Penelitian ini menjelaskan dari sudut pandang keberfungsian individu yang berperan sebagai mahasiswa. Semakin seseorang sering merasakan simptom-simptom tertentu, maka semakin rendah nilai keberfungsian seseorang dalam kehidupannya sehari-hari. Sedangkan semakin jarang atau tidak merasakan simptom-simptom menunjukkan bahwa kondisi individu berada pada kondisi sehat mental dan nilai keberfungsiannya semakin tinggi.

Sejalan dengan penjelasan dari pengertian sehat mental dari WHO yang menjelaskan bahwa kondisi sehat mental yaitu ketika seseorang dapat menggunakan kemampuannya dan menanggulangi permasalahan atau stressor sehingga mampu untuk bekerja secara produktif sebagai mahasiswa. Hal ini dapat dijelaskan oleh hasil penelitian yang menunjukkan bahwa setelah individu menggunakan bentuk coping yang efektif, baik berfokus pada emosi maupun masalah, maka dapat menurunkan tingkat stres seseorang. Saat individu menilai situasi sebagai tantangan, benign positive, atau irrelevant, maka akan memengaruhi emosi individu secara positif. Hal ini menurunkan simptom-simptom yang dirasakan oleh individu, sehingga mahasiswa dapat menjalankan tanggung jawabnya sebagai mahasiswa secara efektif.

Mahasiswa yang menilai suatu situasi dapat diubah, cenderung akan menggunakan bentuk coping yang berfokus pada masalah. Individu akan mencoba menilai terlebih dahulu situasi yang dihadapinya. Saat individu menilai stressor sebagai suatu ancaman, kerugian, atau tantangan bagi dirinya, maka cenderung akan memilih upaya-upaya dalam mengatasi permasalahannya, antara lain mengambil tindakan langsung untuk mengatasi permasalahan, memikirkan langkah-langkah yang akan dilakukan untuk mengatasi permasalahan, mencari saran, nasihat, atau bantuan kepada orang lain untuk mengatasi permasalahan, atau menunggu waktu yang tepat untuk mengatasi permasalahan. Setelah individu melakukan suatu upaya, maka individu akan melakukan penilaian apakah upaya yang dilakukan efektif dalam mengatasi permasalahan atau tidak. Ketika seseorang menilai bahwa upaya tersebut efektif, maka tingkat stres yang dirasakan akan mengalami penurunan.
Penilaian kembali ini dapat mengubah penilaian seseorang dari yang merasa terancam atau merugi menjadi tertantang. Perbedaan penilaian ini memengaruhi reaksi yang ditimbulkan. Pada individu yang menilai stressor sebagai tantangan, maka akan menilai bahwa apa yang sedang dihadapinya menimbulkan emosi positif seperti bergairah atau semangat. Meskipun stressor dirasa membebaninya, namun individu tersebut bersemangat dalam mengatasi permasalahannya. Individu lain yang menilai upaya yang dilakukannya efektif dalam mengatasi permasalahan, maka akan menilai stressor sebagai situasi yang tidak berdampak lagi terhadap dirinya. Kondisi ini dikenal sebagai istilah irrelevant. Selain itu, individu yang menilai coping yang digunakan efektif mengatasi permasalahannya dapat menilai stressor sebagai situasi yang positif dan menguntungkan bagi dirinya, sehingga reaksi emosi yang dihasilkan pun akan positif. Hal ini menjelaskan bagaimana terjadinya penurunan simptom-simptom yang dirasakannya. Individu yang berhasil menurunkan simptom-simptom dapat mengarahkan kepada kondisi sehat mental, sehingga individu dapat menjalani aktivitasnya kembali.

Individu yang menggunakan coping yang berfokus kepada emosi menunjukkan bahwa stressor yang dinilai tidak dapat diubah, sehingga cara mengatasi stres yaitu dengan cara mengatur respon emosional dalam rangka menyesuaikan diri dengan dampak yang akan ditimbulkan oleh suatu kondisi atau situasi tertentu yang dianggap penuh tekanan. Menurut Lazarus \& Folkman (2006), emotion focused coping merupakan sekumpulan proses kognitif yang diarahkan untuk mengurangi tekanan emosional dan mencakup strategi menghindari, meminimalisasi, menjaga jarak, selektif memilih perhatian, perbandingan positif, dan mencari nilai positif dari sebuah peristiwa negatif.

Pada individu yang menilai bahwa stressor tidak dapat diubah, maka akan menggunakan bentuk coping yang berfokus terhadap emosi. Adapun upaya yang dilakukan dalam mengatasi stres yaitu dengan mencari dukungan simpati atau moral dari orang lain, menilai kembali stressor sebagai situasi yang positif, menolak untuk percaya bahwa individu sedang mengalami stres, menerima atau menyesuaikan dirinya dengan stressor, mencari ketenangan dengan memohon pertolongan kepada tuhan, atau membuat stressor sebagai sebuah lelucon. Hal ini tidak berbeda dengan penggunaan problem focused coping yang telah dijelaskan sebelumnya, dimana individu yang menilai stressor sebagai suatu ancaman atau kerugian, maka akan menghasilkan reaksi emosi yang negatif, terutama pada situasi yang dinilai tidak dapat diubah situasinya, misalnya kehilangan orang terkasih atau mengalami bencana. Hal yang dilakukan akan mengarah pada upaya dalam mengatur respon emosional. 
Individu yang menilai upaya yang dilakukannya efektif untuk mengatur respon emosionalnya, maka reaksi emosinya akan berubah. Individu cenderung akan merasa lebih tenang dan dapat mengendalikan dirinya, sehingga upaya yang dilakukan selanjutnya dapat mengarah dalam mengatasi permasalahan atau melanjutkan kembali kehidupannya sehari-hari. Individu akan melakukan penilaian kembali, dimana pada saat awal individu menilai stressor sebagai situasi yang mengancam atau merugikan dirinya, kemudian setelah melakukan upaya yang berfokus kepada emosi, maka akan menilai situasi tersebut sebagai suatu hal yang positif atau irrelevant. Salah satunya, pada saat individu melakukan upaya penilaian kembali stressor sebagai situasi yang positif bagi dirinya, maka individu tersebut akan menilai stressor sebagai positif dan menguntungkan dirinya. Begitupula saat individu melakukan denial atau menolak sedang mengalami stres, maka individu akan mengarah kepada kondisi irrelevant. Jika hal ini sukses dilakukan oleh individu, maka reaksi emosi negatif saat awal penilaian akan mengalami penurunan. Hal ini ditunjukkan dengan penurunan atau peniadaan simptom-simptom indikasi gangguan kesehatan mental.

Pada individu yang menggunakan maladaptive coping, yaitu upaya yang kurang bermanfaat dan kurang efektif dalam mengatasi stressor, individu tersebut cenderung melakukan upaya yang tidak tepat, sehingga efek yang dihasilkan pun tidak menurunkan tingkat stres. Selain itu, meskipun dinilai sukses menurunkan tingkat stres dan merasa lebih tenang, akan tetapi bersifat hanya sementara. Setelah melakukan upaya tersebut, selang waktu kemudian akan merasakan stres kembali. sehingga mengalami peningkatan simptom-simptom gangguan kesehatan mental. Jika individu sering melakukan upaya yang tidak efektif, maka hal tersebut dapat memengaruhi kondisi kesehatan mental dan produktivitasnya.

Penjabaran mengenai bentuk coping yang tidak efektif mengatasi permasalahan ini memengaruhi secara langsung maupun tidak langsung terhadap kesehatan mental. Semakin sering seseorang menggunakan bentuk coping yang tidak efektif dalam menyelesaikan permasalahannya, maka semakin tinggi seseorang menghayati dirinya sedang mengalami stres. Hal ini berdampak terhadap kondisi kesehatan mental, dimana seseorang yang memiliki derajat stres tinggi akan mengarahkan kepada gangguan kesehatan mental tertentu. Mahasiswa akan merasakan simptom-simptom yang dirasakan sebagai kondisi yang tidak nyaman terhadap dirinya sebagai reaksi stres. Akan tetapi, perilaku dari penggunaan bentuk coping yang berulang-ulang akan berpengaruh terhadap kesehatan mental. Hal ini dikarenakan individu berusaha untuk mengabaikan, menghindari, atau usaha tidak efektif lainnya untuk mengatasi permasalahan. Semakin sering individu melakukan perilaku yang maladaptive, maka akan semakin menimbulkan penghayatan tidak mampu yang akan mengarahkan individu terhadap indikasi memiliki gangguan kesehatan mental.

Pada Tabel 2 menunjukkan hasil deskriptif partisipan penelitian dengan variabel yang sedang diteliti, yaitu tingkat stres, penggunaan coping, dan kesehatan mental berdasarkan jenis kelamin. Diketahui bahwa pada partisipan penelitian, tingkat stres yang ditunjukkan dengan skor perempuan lebih tinggi dibandingkan dengan skor laki-laki. Hal ini menjelaskan bahwa perempuan lebih rentan menilai

Tabel 2. Data Deskriptif

\begin{tabular}{|c|c|c|c|c|c|c|c|c|c|c|c|}
\hline & \multirow[t]{2}{*}{$\mathrm{N}$} & \multicolumn{2}{|c|}{ DS } & \multicolumn{2}{|c|}{$\mathrm{KM}$} & \multicolumn{2}{|c|}{ EFC } & \multicolumn{2}{|c|}{ PFC } & \multicolumn{2}{|c|}{$\mathrm{MC}$} \\
\hline & & $\mathrm{M}$ & $p$ & $\mathrm{M}$ & $p$ & $\mathrm{M}$ & $p$ & $\mathrm{M}$ & $p$ & $\mathrm{M}$ & $p$ \\
\hline $\mathrm{L}$ & 138 & 202.3 & $<0,05$ & 197,5 & $<0,05$ & 220,3 & $>0,05$ & 216 & $<0,05$ & 238,4 & $>0,05$ \\
\hline $\mathrm{P}$ & 331 & 248.6 & & 250,6 & & 241,1 & & 242,9 & & 233,6 & \\
\hline
\end{tabular}

$\mathrm{L}=$ laki-laki, $\mathrm{P}=$ Perempuan, $\mathrm{DS}=$ Derajat Stres, $\mathrm{KM}=$ Kesehatan Mental, EFC = Emotion focused coping, PFC

= Problem focused coping, $\mathrm{MC}=$ Maladaptive coping.

Sesuai dengan hasil penelitian yang menunjukkan bahwa derajat stres berperan sebagai mediator pada hubungan bentuk maladaptive coping terhadap kesehatan mental. Saat individu menilai stressor sebagai situasi yang mengancam dan merugikan, setelah menggunakan bentuk maladaptive coping, maka individu akan tetap merasakan hal yang sama dengan tingkat stres pada level yang sama atau cenderung meningkat. Hal ini memengaruhi reaksi yang dirasakan oleh individu yang ditunjukkan dengan peningkatan simptomsimptom yang dirasakan oleh individu. Semakin individu melakukan bentuk coping yang tidak efektif, maka semakin tinggi individu akan merasakan stres, situasi sebagai ancaman dan memimbulkan kerugian. Pada penggunaan coping pada laki-laki dan perempuan, diketahui bahwa perempuan frekuensinya lebih sering menggunakan bentuk problem focused coping dan emotion focused coping dibandingkan dengan laki-laki. Namun, laki-laki dan perempuan tidak memiliki perbedaan dalam penggunaan coping yang maladaptif. Sementara itu pada kesehatan mental, diketahui bahwa perempuan memiliki skor gangguan kesehatan mental yang lebih tinggi dibandingkan dengan laki-laki. 


\section{SIMPULAN}

Derajat stres berperan sebagai mediasi antara hubungan bentuk emotion focused coping, problem focused coping, dan maladaptive coping terhadap kesehatan mental. Dengan demikian, dalam menjelaskan pengaruh penggunaan coping terhadap kesehatan mental, dapat dijelaskan melalui perantara derajat stres dalam proses penilaian kembali. Artinya, peran penilaian kembali setelah dilakukan penggunaan coping dapat menjelaskan status kesehatan mental. Hal ini sejalan dengan kerangka teori Lazarus \& Folkman (1984), yaitu transactional model, dimana coping merupakan proses dinamis untuk memengaruhi kesehatan mental seseorang. Pemilihan bentuk coping yang efektif dapat menurunkan derajat stres dan mengarah kepada kondisi sehat mental. Sebaliknya, pemilihan bentuk coping yang tidak efektif secara berulang dapat mengarahkan kepada kondisi tidak sehat mental. Suatu bentuk coping dikategorikan efektif berdasarkan proses penilaian kembali (reappraisal) setelah menggunakan bentuk coping tersebut. Seorang mahasiswa termasuk dalam kategori sehat mental ketika pemilihan bentuk coping yang digunakan dapat menurunkan tingkat stres. Adapun bentuk coping yang dinilai dapat menurunkan tingkat stres, yaitu emotion focused coping dan problem focused coping. Pada mahasiswa yang termasuk ke dalam kategori tidak sehat mental, yaitu saat menggunakan maladaptive coping dalam menghadapi situasi yang stressful. Bentuk coping yang maladaptif dapat meningkatkan derajat stres, yang artinya tingginya tingkat stres seseorang dapat memunculkan simptom-simptom gangguan kesehatan mental. Penelitian selanjutnya diharapkan dapat menelusuri dari masing-masing bentuk coping dan mengkaji maladaptive coping dengan membaginya berdasarkan emosi dan masalah yang tidak efektif.

\section{DAFTAR PUSTAKA}

Agarwal, Anjna. (2011). Impact of academic stresss upon academic achievement and mental health of the adolescents. International Journal of Management and Social Sciences, 1(1).

Badan Penelitian dan Pengembangan Kesehatan Kementrian Kesehatan RI. (2013). Riset kesehatan dasar. Diakses dari https://kemkes.go.id/resources/download/gene ral/Hasil\%20Riskesdas\%202013.pdf

Badan Penelitian dan Pengembangan Kesehatan Kementrian Kesehatan RI. (2018). Hasil utama Riskesdas 2018. Diakses dari https://kesmas.kemkes.go.id/assets/upload/dir _519d41d8cd98f00/files/Hasil-riskesdas2018_1274.pdf
Behere, S., Behere, P., \& Yadav, R. (2011). A comparative study of stres among students of medicine, engineering, and nursing. Indian Journal of Psychological Medicine, 33(2), 145.

Beusenberg, M., Orley, J.H., \& World Health Organization. (1994). A user's guide to the Self Reporting Questionnaire (SRQ). World Health Organization, Division of Mental Health. Geneva: World Health Organization.

Carver, C.S., Scheier, M.F. \& Weintraub, J.K. (1989). Assessing coping strategies: A theoretically based approach. Journal of Personality and Sosial Psychology, 56(2), 267-283.

Chen, Su Yen., Lu, Luo. (2009). After-school time use in Taiwan: Effects on educational achievement and well being. Adolescence, 44(176), 891.

Cohen, Sheldon., Kamarck, Tom., Mermelstein, Robin. (1983). A global measure of perceived stress. Journal of Health and Social Behavior, 24(4), 385-396.

Hayes, Andrew F. (2013). Introduction to mediation, moderation, and conditional process analysis: A regression-based approach. New York, NY: The Guilford Press

Lazarus R.S., \& Folkman, S. (1984). Stress, appraisal, and coping. New York: Pearson Education, Inc.

Lazarus, R.S., \& Folkman, S. (2006). Stress \& emotion: A new synthesis. New York, NY: Springer Publishing Company, Inc.

Nolen-Hoeksema, Susan. (2010). Abnormal psychology (5th ed.). New York: McGrawHill Companies, Inc.

Pusat Data dan Informasi Kementrian Kesehatan RI. (2016). Situasi dan pencegahan bunuh diri. Diakses dari https://pusdatin.kemkes.go.id/article/view/191 03000001/infodatin-situasi-dan-pencegahanbunuh-diri.html

Sentani, Sherly R.E. (2016). Gambaran bentuk coping stress mahasiswa Fakultas Psikologi Universitas Padjadjaran yang mengalami stress akademik. Skripsi: Fakultas Psikologi Universitas Padjadjaran.

Sentani, Sherly R.E. (2020). Pengaruh derajat stress terhadap kesehatan mental melalui perantara coping berdasarkan tipe kepribadian pada mahasiswa di Kota Bandung. Tesis: Fakultas Psikologi Universitas Padjadjaran.

Struthers, C., Perry, P., Menec., V. (2000). An examination of the relationship among academic stress, coping, motivation, and performance in college. Research in Higher Education, 41, 581-592.

World Health Organization. (2014). Mental health: A state of wellbeing. 
World Health Organization. (2016). World health statistics 2016: Monitoring health for the SDGs. Diakses dari https://www.who.int/gho/publications/world health_statistics/2016/EN_WHS2016_TOC.p df?ua $=1$ 